\title{
John Harris
}

\section{A Paradox of Multicultural Societies}

Acceptance, perhaps even celebration, of cultural diversity is now orthodox. No longer are immigrants or the descendents of immigrants, expected to submerge themselves without making any waves beneath the dominant culture. Nor are indigenous minorities or migrant workers required to assimilate themselves with minimum visibility into an amorphous whole.

This acceptance of cultural diversity, whatever its motive, is expressive of, and justified by, a belief in equality. A multicultural society cannot hope to treat its citizens as equals unless it is also prepared to show equal concern and respect for their cultures.

This is a fairly straightforward point but a vital one. Culture and cultural identity are of quite crucial significance. Most obviously culture is an important source of a person's sense of her own identity, of who she is and where, and to what, she belongs. Cultures are classically centred on a religion [1] or on some other set of deeply held beliefs, but culture ranges far wider than this. Acceptance of other cultures' equal right to exist, or to co-exist, involves not simply their freedom to believe, but also to be. Culture is not just a matter of doctrine but also of lifestyle. It includes as T. S. Eliot remarked, "all the characteristic activities and interests of a people" [2]. But not only of 'a people', also a group or class [3].

So, to deny respect to someone's culture can hardly fail to be insulting; and in that it will inevitably gainsay either their religion or perhaps some other deeply held beliefs and also their way of life, or some important aspect of their way of life, injury will be added to insult. And part of the added injury they suffer will be the injury of suffering injustice. A recent writer on multicultural education puts this point very well, P. H. Walkling [4] notes the injustice of requiring "a man crassly to accept the unimportance or worthlessness of the things he holds most dear" and argues that this is

in extreme cases, to threaten his very existence as a moral being. Also, to deny him the right to pass on these things to his children through the medium of formal education with the authority of the wider society behind it, is to suggest that they, too, are of little importance unless they become assimilated into the 'host' culture -and he knows that in that direction lie a pair of unacceptable alternatives: either the child's alienation from home and family, or rejection by the child of whatever benefits schooling has to offer in the new society in which the migrant knows his child will have to live... [5]

It was perhaps considerations of this sort that lead the Commission of the European 
Communities to direct member states to provide inter alia "a place in the school syllabus for the language and culture of origin of the migrant workers child" [6]. The Commission further tells us that "the aim of the ... directive is to commit the member states to take such measures to provide migrant workers' children with equality of opportunity with the children of the host country" [7].

Indeed, it is in discussions about multicultural education that the varying conceptions of what it might be like to fulfill the demands for a multicultural society have been most frequently rehearsed. This is not surprising, for education perhaps more than any other community resource is animated by the spirit of equality. Moreover, because it is for the most part a public resource, and attendance at and obedience in schools is a legal requirement, it is one of the major points at which a society's commitment to equality is made manifest. (For this reason also, schools are a good place to look for evidence of the particular conception of equality which a society endorses.)

Now certainly few educational systems have ever embraced the principle of showing children the same concern and respect as is shown in adults [8], but it is broadly supposed, that within the systems each child is shown the same concern and respect as that accorded to any other. And it is the belief that this is what is required of them that leads many teachers and education authorities to accept that they are discharging this obligation if they attempt equally to respect the cultures of all children in the school, irrespective of the content of those cultures. Now it is this commitment, whether by teachers or any other people or organisations, including the state itself, which highlights a fundamental problem and perhaps a paradox about cultural equality.

\section{The Paradox}

The problem arises in connection with any culture which does not equally respect its own members. It looks as though a society committed to equality [9] and containing such cultures or sub-cultures within it, is caught in a genuine and uncomfortable dilemma. If the society wishes to show to each individual the same concern and respect that it accords to any, then it may be required to outlaw, frustrate or at the very least condemn, important features of a constituent and discriminatory culture. While if it respects all cultures equally, a society may find itself endorsing culturally enshrined inequalities.

For example, a culture which discriminates against women, which denies them equal opportunities, equal freedom, or equal standing with men in their community, may itself require that, as a culture, it be accorded the same concern and respect as that commanded by any other culture within the society.

How are we to resolve this paradox? Are we to respect cultures and thereby endorse the unequal treatment of persons, or insist on equality for individuals at the expense of insult and injury to their culture? Or, is there perhaps some way of dissolving rather than resolving these questions?

\section{Theory and Practice}

The classic method of dissolution is to re-define the 'true' nature of the culture so that it seems not essentially to involve vicious discrimination. This is usually achieved by showing that practice is at variance with theory and by giving cultural priority to theory.

What matters of course is the practice of a culture and the beliefs of its adherents as expressed both in their language and in their way of life. These may well be at variance with some interpretation of their holy book or other formal code, but to respect their culture is to respect the way that they choose to live, not the way that they ought consistently to choose to live. Bertrand Russell [10] makes this point part of his critique of Christian cultures. 
Reminding an audience that Christ had said "Resist not evil, but whosoever shall smite thee on thy right cheek turn unto him the other also" he continued...

it is not a principle that as a matter of fact Christians accept. I have no doubt that the present Prime Minister (Stanley Baldwin) for instance is a most sincere Christian but I should not advise any of you to go and smite him on one cheek. I think you might find he thought this text was intended in a figurative sense.

Then there is another point which I consider is excellent. You will remember Christ said: 'judge not lest ye be judged'. That principle I do not think you would find was popular in the law courts of Christian countries. I have known in my time quite a number of judges who were very earnest Christians and they none of them felt that they were acting contrary to Christian principles in what they did.... Then there is another maxim of Christ which $I$ think has a great deal in it.... He says 'if thou wilt be perfect, go and sell that thou hast and give to the poor.' That is a very excellent maxim but, as I say, it is not much practiced. [11]

The same dissonance between theory and practice is noticed by a recent writer on Islam [12]:

The status of women under theoretical Islam is something unique, dignified and something that has no similarity in any other system. Of course this is very difficult to prove, by looking at the Muslim women in Arabia, the Magreh (sic.) and the Indian sub-continent. But let us state the theoretical facts first.

Women in Islam are generally recognised as equal to men ... both the Quran and the traditions of the prophet Muhammad emphasise the sacred nature of women's right much more often than they emphasise the rights of men... The Islamic law is on their (the women's) side and geared to the improvement of their material and social position, without being patronising. They could never sanction any custom of (sic.) tradition that does injury or wrong to women.

The author, Saliha Basit, herself a Muslim, continues rather ruefully, "So much for theory. The practice however contrasts sharply..."

\section{Islamic Law}

Ms Basit is not of course addressing herself to the problem of cultural equality but to that of the position and treatment of women within Islam. It is far from clear that she is right even about Islamic Law. The Quran [14] for example specifically provides for a man to take (at least) up to four wives if he treats them equally, but women cannot multiply their husbands on the same terms. The inheritance and property laws are also, in most circumstances, weighted heavily in favour of men, although these are of course influenced by custom and vary wildly from community to community within the Islamic world [15]. Similarly Islamic law allows men almost total freedom to repudiate their wives whenever fancy takes them, whereas wives may claim judicial dissolution of marriage on only four very specific grounds [16].

Ms Basit is clearly too optimistic about the egalitarian spirit of Islamic Law. But even more important is the practice of Islamic cultures, and this as she is at pains to point out, makes fewer concessions than the law. She notes among many other things the practice "prevalent almost everywhere in the Muslim world of depriving women of sunshine, fresh air and healthy movement by restricting them to the four walls of the home" [17]. Part of the nervousness about 'healthy movement' comes from the women themselves since it is commonly very important that their virginity be bloodily obvious on their wedding night. Naila Minai, another recent woman commentator on the position of Islamic women asks:

Must women born with irregular hymens risk rejection on their wedding night? Must 
they avoid invigorating physical exercise for fear of breaking the sacred membrane?

Should every woman be constrained to explain her behaviour because her virtue

must not fall under the slightest of suspicions? [18]

This last remark refers to the widespread requirement that Muslim girls be able to account for all their movements and be chaperoned where necessary, lest there be suspicion of any impropriety. It is the consequences of these attitudes which involve the severe restriction of women and girls and, for the latter, involves their withdrawal from many activities that are here part of the normalal education provision, that societies like ours are called upon to protect and even endorse in the name of cultural equality.

It is clear that the paradox of cultural equality cannot be dissolved by distinguishing between theory and practice and by giving cultural priority to theory. For so long as the members of a particular culture do not practice what is preached at them the paradox remains. And indeed, as we have seen, Islamic women would not be a great deal better off if the law, as far as it can be readily understood, were strictly adhered to. Perhaps we should also note before moving on that there is some considerable support for the view that many of the severely anti-feminist elements of Islamic cultures pre-date the prophet and it is arguable that Islam, in its day, was a reformist and humane innovation that considerably improved the position of women [19].

However this may be, the position of women in Islam today makes Islam the most prominent example of a culture which discriminates openly against over half of its own members while claiming for itself equality of concern and respect within a larger culture which has rejected such discrimination (albeit very recently and belatedly). For this reason and because it is one of the foremost world cultures, long and well established and highly influential, it is a paradigm case of a culture which presents a society like our own with what I have called 'the paradox of multicultural societies'. I shall accordingly give Islam the prominence due to a paradigm case in what follows [20].

It must however be emphasised that there are a number of other openly discriminatory cultures including our own [21] in the very recent past (and many would claim still so in a number of respects). Rastafarians, if they count as constituting a culture, would also be a clear example but there are others. Most organised religions including Judaism and almost all Christian denominations are undoubtedly 'sexist' in their priesthood and ritual. One might also plausibly claim that they are openly discriminatory in their 'theory' or law. In practice however most Christians and Jews are not dominated by the inegalitarian aspects of their respective religions, and so do not present a multicultural society with the same paradoxical dilemmas. There are of course strict Christian and Jewish sects which are comparable to Islam in this respect and in these cases the same arguments will apply with the same force.

The caste system as it arises within Hinduism would be another major example. Cultural beliefs to the effect that Harijans are condemned to the disadvantages and disqualifications of their low status by something as arbitrary and unalterable as their birth would clearly raise difficulties for any multicultural society committed to equality for all its citizens, and which for example faced the prospect of including such ideas in a school curriculum. Harijans of course differ from many other Hindus as to the cultural necessity of their low status and in that they do not consent to it, the dilemma they present to egalitarian multiculturalists is less acute, as we shall see below.

The problem of discrimination against members of particular castes within Hinduism, while a genuine one for a multicultural society like that of India, containing a population which includes large numbers of more or less caste-conscious people, is not a major issue in most Western societies. For this reason I will continue to take the more familiar case of cultures which discriminate against women as the principle example in the arguments that follow.

Although I am here concerned with the paradox as it arises within a particular multicultu- 
ral society that contains discriminatory constituent cultures or sub-cultures, it is worth noting that the paradox is perhaps more prominent in what might be called the 'world society'. Any nation state which discriminates against some, or some groups of, its own citizens but which claims for itself equality of concern and respect with other nations, presents the world community with the same dilemma. Of course much of the internal discrimination practiced by some states is just political thuggery but there are many cases where such discrimination is culturally based. Indeed, the suppression by Britain of slavery in the last century and the open attacks by the Royal Navy on the slave ships of other nations might well be seen, and was seen, as a flagrant, high-handed and insensitive rejection of the deeply held beliefs and cultural practices of other societies. These societies might well have claimed that they were entitled to the same concern and respect for their practice of slavery as Britain claimed for the rejection of such a practice. However, in that case Britain made no claim to be attempting to show equality to those societies nor to be attempting to respect their cultures nor their practices.

We must now return to the issue at hand, to the question of how a culture like our own, which is avowedly and rightly willing to do all it can to show equality of concern and respect to all its citizens and which recognises that it cannot hope to do this unless it is also willing to show equal concern and respect for their cultures, is to cope with the paradox which constituent discriminatory cultures present.

\section{Cultural Relativity}

Walkling, whose strong championship of justice for minority cultures we noted above, believes he has an answer to this question, at least as far as education is concerned. He makes recommendations which claim the advantage of being morally and culturally neutral, appealing to no principles other than educational ones. On Walkling's account we are required to include in the educational curriculum only "the worthwhile features of any way of life" [22] and this in practical terms enables us "in circumstances where it is appropriate to include much material from the cultural traditions of minorities..." [23]. Now this is to take back almost everything. For the power of Walkling's plea for justice is precisely its defense of all the things members of the particular culture themselves hold most dear. These qualifications, involving as they do, our judgements as to the worth of elements of their culture, and requiring the inclusion of material only where appropriate (in our judgement) amount to the merest tokenism. Tokenism because whatever the quantity of such material and however faithfully introduced, the qualifications will effectively deny members of the minority culture the right to pass on to their children the things they hold most dear "though the medium of ... education with the authority of the wider society behind it". If we attempt to exclude the discriminatory aspects of any cultures that disadvantage women or people of low caste we may be effectively requiring "a man crassly to accept the unimportance or worthlessness of the things he holds most dear".

I am not saying that we should not exclude these things, perhaps we should. Only that we cannot do so and remain multiculturalists in that powerful sense which requires us to show equality of respect to other cultures and especially to those aspects of their culture that the members of the culture themselves value.

If the paradox of cultural equality cannot be dissolved by distinguishing between theory and practice and giving cultural priority to theory, nor by arbitrarily including only those elements of which we approve, can it be resolved in any other way? We are certainly reluctant to accept the intractability of this paradox and the reason is perhaps our acceptance of the very principles that give rise to it. If a belief in equality will not help us, can we not appeal to other moral principles that we hold for guidance here? Does not our commitment say to justice or tolerance or respect for persons or even liberty require us precisely to be tolerant of, to show 
respect for, to do justice to and permit freedom for, all other cultures irrespective of their content?

Although primarily posing a problem for the demands of equality, inegalitarian cultures also pose problems for other principles which might be deployed in their defence.

\section{Liberty}

Do we not believe that others should have the right to choose for themselves how they should live and what they will accept, that they should have the freedom to live as they choose and believe what they like? As Mill so persuasively remarks:

As it is useful that while mankind are imperfect there should be different opinions, so it is that there should be different experiments of living; that free scope should be given to varieties of character short of injury to others; and that the worth of different modes of life should be proved practically, when anyone thinks fit to try them. [24]

The problem here of course is the very elusive issue of consent. If for example, women against whom their cultures discriminate, can genuinely be taken to consent to being treated unequally, if this is really what they want for themselves, then this autonomous choice (if that is what it is) might well be taken to outweigh egalitarian or other considerations. It would still of course be paradoxical to defend this unequal treatment with an argument from equality rather than one say from Liberty (and if Ronald Dworkin [25], for example, is right to claim that the principle of Liberty presupposes and depends on a 'deep' theory of equality, then the paradox might indeed be radical).

There are two issues here, the first is the question as to whether or not such women freely consent to the way they are treated? The second is whether or not a libertarian is required to respect this choice in the circumstances in which it is made? This problem of the extent to which a culture tyrannises over its members so that they may be robbed of the possibility of free choice of lifestyle is one of which John Stuart Mill was acutely aware. For the passage above, which appears to defend the right of particular cultures to freely practice what they believe, continues with a warning against cultural tyranny.

Where, not the person's own character, but the traditions or customs of other people are the rule of conduct, there is wanting one of the principle ingredients of human happiness, and quite the chief ingredient of individual and social progress. [26]

It is doubtful whether most victims of discrimination do genuinely consent to the way they are treated, but even if they do, someone who respects liberty must look at why they consent. Mill's argument here is important both for its consequences for our views about the nature of multicultural societies and because it tells us something about the proper limits of multicultural education. I will therefore let Mill speak for himself for long enough to make his point:

though the customs be both good as customs, and suitable to him, yet to conform to custom merely as custom, does not educate or develop in him any of the qualities that are the distinctive endowment of a human being... He who does anything because it is the custom makes no choice... The faculties are called into no exercise by doing a thing merely because others do it. [27]

We should be quite clear that Mill is not saying that we should frustrate, ban, nor yet outlaw such servile adherence to custom. But it is one thing to permit such practices and quite another to respect them. A respect for the liberty of others, for their freedom to live their own lives as they choose presupposes that it is their own lives they are leading and that they are choosing. In any event, such a respect for liberty does not oblige us to protect or facilitate such practices, to afford them a platform, shield practitioners from criticism of their behaviour and 
beliefs, or from knowledge of our attitude to their beliefs or from knowledge or advocacy of alternatives.

We should also remember that the practices in question are themselves anti-libertarian in another and more obvious way, in that they are restrictive of the freedom of the very individuals involved. The customs we are speaking of frequently deny women, for example, education, or higher education, opportunities of employment or of an independent career; they impose restrictions on movement, exercise, sport, fresh air and dress and most importantly, place women comprehensively at a disadvantage. It looks as though it would be very difficult to defend such practices on libertarian grounds when this would involve us in endorsing practices which are themselves profoundly anti-libertarian.

\section{Tolerance}

If not our commitment to the ideal of liberty, surely our tolerance requires us to respect all other cultures and because cultures are classically [28] (though not necessarily) centred on a religion, is not our tolerance of other cultures part of our obligation to show tolerance to other religions? Whatever else may be said of the line of argument I have been developing, it seems to demand a withdrawal of tolerance towards inegalitarian cultures. What does tolerance require here?

Let us deal with tolerance of religion first since religious tolerance has been hard won and it is now a part of the constitution of many nations, notably the United States of America. Religious tolerance I suppose requires us to permit others to believe what they like about god and its relationship with people, the universe and everything. The cutting edge of this tolerance is that we should not punish others for possessing or expressing such beliefs, nor inhibit nor prevent them from so doing. A problem arises when people purport to dictate how others should live and claim religious grounds or religious authority for so doing. For the question 'how should people live?' is a moral question, perhaps the moral question and no moral position can be founded on the authority of religion or indeed or any other authority. Bertrand Russell showed this decisively when he noted that "Theologians have always taught that God's decrees are good and that this is not a mere tautology: it follows that goodness is logically independent of God's decrees" [29].

A belief in the importance of religious tolerance cannot then commit us to acceptance of moral positions grounded in the authority of religion. Should we then tolerate inegalitarian cultural practices on any more general grounds? The only argument that I can think of with any merit is a utilitarian one. It involves the reminder that societies usually contain what may be thought of as vast reserves of free-floating malice, which circulates constantly looking for a place to settle. It is therefore exceptionally dangerous to provide any grounds for intolerance, even of an inegalitarian and sexist minority culture. To do so is to provide ammunition for bigots, to prepare the ground on which malice can settle, and to perpetuate the very attitudes that tolerance requires us to suppress. We should of course, be very wary of doing this, but worrying as this possibility is, it serves rather to sharpen the paradox we have been considering. For our commitment to tolerance and our disinclination to serve the interests of prejudice appears to require us self-defeatingly, to tolerate discrimination against women. A tolerant society surely is not one which encourages or condones institutionalised arbitrary discrimination nor the subjection of one sex to another.

\section{Justice and Respect for Persons}

Appeal to the principles of justice and of respect for persons re-present the paradox with an undiminished force which is soon appreciated. For as we have seen, while it is unjust to require a man "crassly to accept the unimportance or worthlessness of the things he holds most 
dear" it is equally unjust to women to require them to uphold the values of men, values which are moreover profoundly insulting and disadvantageous.

Similarly, while it is incompatible with respecting someone to treat as of little importance things that they hold most dear it is equally incompatible with respecting women as persons to so order their lives that they are prevented from developing aspirations and life plans that are distinctly their own.

\section{The Morality of Discrimination}

There are some important further questions that we must now consider. The first is the question of whether or not our judgement as to the morality of the particular cultural practices that generate the paradox can contribute to its dissolution. Here we might adapt an argument that Ronald Dworkin [30] constructed for Lord Devlin and which arose in the context not of cultural, but of sexual practices. If, so the adapted argument goes, the cultural practices which threaten the egalitarian spirit of our social institutions and our commitment to equality for women, can be shown to be immoral, then

the freedom for an individual to pursue them counts for less. We do not need so strong a justification in terms of the social importance of the institutions being protected, if we are confident that no one has a moral right to do what we want to prohibit. [31]

We are not of course considering the question of the prohibition of discriminatory cultures, but that of whether or not our commitment to equality and to the establishment of a just multicultural society requires us to show an equal concern and respect for such cultures. The answer to this question might be easier if we could be confident that no-one has a moral right to discriminate against women. Here again the elusive issue of consent arises to complicate the issue. We might be confident that there cannot be a moral right to discriminate against women against their wishes. If women genuinely choose to live a life of self-imposed restraint and limited opportunity, can it be moral to discriminate against them and their culture for so doing?

One question we might press here is that of whether the status of women in sexist cultures is like that of women in England in the Middle Ages, or the nineteenth century or indeed at any time prior to the present decade? It seems open to us (perhaps even morally required of us) to criticise the morality of the treatment of women in England in say the nineteenth century even though it is probable that many of even most women did not feel oppressed or make known any objections to their status or situation. Suppose someone (perhaps Napoleon if he had (a) been 'liberated' and (b) possessed a vastly more efficient and successful navy) had withdrawn institutional support for discrimination against women and had mounted a thoroughgoing critique of the attitudes which lie behind it. We might well now applaud the actions of such a man. And if such a Napoleon had not gone so far as to prohibit the cultural subservience of women but had rather declined any official support for or protection of the practices which perpetuated such subservience, then he would have needed to be less clear as to their immorality, or less clear as to the degree of their immorality, than would have been required to justify their prohibition.

The problem remains however that the clearer we are that discrimination against women or those of low caste is immoral the less strong a justification we need for our withdrawal of official support from immoral practices and the cultures which maintain them. But the less justification we produce for our differential treatment of particular cultures within our multicultural society and the more we consequently select among the cultural practices we are prepared to endorse, then of course and pro tanto, the less we can hope to show to those 
cultures and their members, that equality of concern and respect to which our commitment to a multicultural society commits us.

\section{Reverse Discrimination}

The next question to be considered is whether the important and radical idea of 'reverse discrimination' can provide a respectable solution to the paradox. It might be possible to argue that the discrimination against women practiced by Islamic and other cultures should be both accepted and protected, at least in a multicultural society like our own where such cultures are also vulnerable minorities, because to do so would constitute a justified form of reverse discrimination. The argument here would be that reverse discrimination standardly involves discrimination against some whites in the provision of educational opportunities or in the provision of employment and is justified in order to promote greater equality within society as a whole and because it operates to break a cycle of deprivation by creating opportunities for blacks who were formerly excluded. In a related way, acquiescence in and institutional support for the continued discrimination against the women of Islam, is justified because it is required to create and sustain greater equality in society as a whole by according to Islamic cultures the same concern and respect that is shown to other non-discriminatory cultures and without which they would be unfairly disadvantaged.

So that our promotion or rather our defence of the discrimination against women practiced within a constituent culture would not be paradoxical precisely because, like more familiar forms of reverse discrimination, it would have the effect of creating a more just and egalitarian society. Moreover, general welfare would also be promoted because the full acceptance of minority cultures will reduce racial tension and remove the grounds for resentment that minority cultures feel when they know that their practices are not endorsed by the institutions of the society in which they live.

There are two problems here, one of which is a consequence of the other. The first is that reverse discrimination is of its very nature a temporary expedient designed as a shortcut to the redress of self-perpetuating injustice. Once the cycle of deprivation is broken the reverse discrimination must be abandoned, both because its reason d'être has disappeared and because if it is not then abandoned it will lead to the resentment of those who are disadvantaged by its operation and the consequent emergence of the sorts of social disorder that it was in part introduced to minimise.

But protecting discrimination against Muslim women as a temporary measure of reverse discrimination to be removed as soon as Muslims are 'liberated' by daily contact with the rest of us, will not do at all. For then, so far from being a measure that involved respecting their culture it would effectively offer the most profound of insults, suggesting that they would only be tolerated for so long as it would take them to see the light and reform themselves from within. On the other hand, if it were to be argued that in this special case the reverse discrimination could not be thought of as a temporary measure because of the insult that such a suggestion would inevitably involve, then again, a crucial part of its justification would be missing. For if we were to contemplate permanently institutionalising the subservience of women as a form of reverse discrimination in favour of Islam the argument that this measure could conceivably promote justice or equality in society as a whole would cease to have any plausibility. It would then be clear that such 'reverse discrimination' would be self-defeating and the paradox would re-appear with undiminished force.

\section{Protection or Challenge?}

The final difficulty that we must now consider is the question of whether it is in reality more 
respectful to protect or to challenge those beliefs or practices of other cultures with which we disagree. Walkling makes the point well and comes down on the side of challenge:

The possibility of a pluralistic society depends upon the possibility of understanding people and their beliefs. It must if it is to be worth anything at all, provide a dynamic context in which people's beliefs are exchanged, defended, argued about, converted, retained, assessed, ignored ostentatiously, and so on: all the reactions people have to the beliefs of other people whom they take seriously. [32]

Certainly, part of what it is to respect someone is to take them and their beliefs seriously, and this may well involve among other things challenging those beliefs where appropriate. But the problem for a pluralistic society like ours is that of whether, having challenged and whatever else, those beliefs and practices, we are or are not to lend them institutional support and protection. When, at the end of the argument, the members of that other culture say 'thank you for taking me so seriously as to put your objections to my beliefs and way of life so cogently to me and for respectfully listening to my defence. Now kindly act consistently with your own belief in equality of concern and respect for all citizens and permit me to go on respecting the ways of my people and afford me the opportunity that you grant yourself, of living as I choose to live and of preserving and passing on to my children my culture and its values with the same authority and institutional support and protection that you give to your own'.

\section{Racism and Sexism}

The problem then is and remains, that of how a society which contains discriminatory cultures or sub-cultures can either show equal concern and respect for its members while withholding this from some constituent cultures, or how it can show equality of concern and respect for all cultures without endorsing discrimination against many individuals. The general form of the problem at least is by no means a new one. Liberals and democrats have had to face similar problems [33] in deciding how to respond to illiberal and undemocratic movements that arise within and threaten the constitution of liberal democratic societies. However, despite the familiarity of the form of the problem there has been a fairly comprehensive taboo on its discussion in the context of multicultural societies and in the growing literature on multicultural education. Now of course, those interested in creating some viable conception of a just multicultural society, and in doing so in part via multicultural education, have many different conceptions of what they wish to achieve and varied strategies and priorities for achieving it. As a recent writer [34] on multicultural education has observed:

many people who are concerned to promote what they call multicultural education are less concerned about initiating children into several cultures than about seeking to change the institutional racism of our educational system. [35]

But the problem just is that while we must eradicate the institutional racism of our society and while equally we must make it possible for all cultures to pass on to their children the things they hold most dear 'through the medium of formal education with the authority of the wider society behind it', the very same principles that mandate the achievement of these goals also and for the same reasons require the abolition of the institutionalised sexism of certain cultures.

\section{Acknowledgements}

I am grateful to Norman Calder of the Department of Near Eastern Studies, University of 
Manchester, for his generous advice on Islamic Law and to R. K. Elliott for helpful comments.

Correspondence: John Harris, Department of Education, University of Manchester, Oxford Road, Manchester M13 9PL.

\section{NOTES AND REFERENCES}

[1] Eliot, T.S. (1967) Notes Towards the Definition of Culture, p. 15 (London, Faber \& Faber).

[2] Ibid., p. 31.

[3] Ibid., p. 27.

[4] Walkling, P.H. (1980) The idea of a multicultural curriculum, Journal of Philosophy of Education, Vol. 14, No. 1.

[5] Ibid., p. 88.

[6] Commission of the European Community: Proposal for a Council Directive on the education of the children of migrant workers. Comm. (75) 390 Final Version. My emphasis.

[7] Ibid.

[8] Though I think there are good arguments for their so doing. See my The political status of children, in: Graham, Keith (Ed.) Contemporary Political Philosophy (Cambridge University Press, 1982).

[9] Even in the very minimal sense of equality of opportunity.

[10] Russell, Bertrand (1964) Why I am not a Christian, pp. 10-11 (London, Allen \& Unwin).

[11] Ibid.

[12] Basit, Saliha (1979) The Guardian, 3rd December.

[13] Ibid.

[14] Quran. Sura IV, verse 3.

[15] See for example Schacht, Joseph (1964) An Introduction to Islamic Law, p. 171 ff. (Oxford University Press).

[16] See Anderson, Norman (1976) Law Reform in the Muslim World, p. 120 ff. (London, Athlone Press).

[17] Basit, op. cit.

[18] Minai, Naila (1981) Women in Islam, p. 155 (London, Murray).

[19] For this see Coulson, N.J. (1964) A History of Islamic Law, p. 13 ff. (Edinburgh University Press).

[20] Islam is also a particularly good example in the context of debates about multicultural education in the United Kingdom where Muslim children are well represented in many schools. Although I concentrate in this paper on discrimination against women there are good reasons for a parallel argument about all cultures which discriminate against children (and that means all cultures) and these good reasons I have set out elsewhere: see note [8] above.

[21] It is of course difficult to talk of 'our own' culture in these multicultural times but I believe the sense is reasonably clear.

[22] Walkling, op. cit., p. 94.

[23] Ibid.

[24] Mill, John StuaRt (1962) On Liberty, chapter III (London, Fontana).

[25] Dworkin, Ronald (1977) Taking Rights Seriously, chapter 6 (London, Duckworth).

[26] Mill, op. cit.

[27] Ibid.

[28] Eliot, op. cit.

[29] I am relying on A. J. Ayer for the precise formulation of Russell's argument, The Times, November 61981.

[30] Dworkin, op. cit., chapter 10.

[31] Ibid., p. 246.

[32] Walkling, op. cit., p. 94.

[33] See for example PoPPer, Karl (1966) The Open Society and Its Enemies, Vol. 1, p. 265 (London, Routledge \& Kegan Paul).

[34] Phillips-Bell, M. (1981) Multiracial education, Multiracial Education, Vol. 10, No. 1.

[35] Ibid. See also Phillips-Bell, M. (1981) Multiracial education: a critique of Walkling and Zec, Journal of Philosophy of Education, Vol. 15, No. 1. 